\title{
Historic urban fabric as basis for further urban renewal: later 20th century public urban interventions in Ciutat Vella, Valencia
}

\author{
César D. Mifsut García \\ Escuela Técnica Superior de Arquitectura. Universitat Politècnica de València. Valencia, Spain \\ E-mail: cmifsutg@gmail.com
}

\begin{abstract}
Valencian old town -locally called Ciutat Vella- suffered a huge transformation along 20th century. It was almost the whole city in 1900, and became less than $5 \%$ of the urban area in 2000. There was not only a process of architectural replacement, but a complete series of plans trying to update the historic spaces. There were three specific stages for those town planning proposals, made by public administrations but not always from public execution. The first group was developed at the beginning of the century following hygienic principles, with both public planning and execution. A second group, in the middle of the century, collected a series of punctual urban corrections and only one huge new urban axis -Avenida del Oeste-; all them specially built by private investors. The third, final group of interventions occurred after Bologna protection principles, and its specific treatment of degraded areas into city centre. In this later, most recent interventions can be studied the hard influence of previous urban fabric in the process of creating new urban spaces. Both historic slots' and blocks'geometry provide the definition for further street sections; but, in the other hand, those new street edges-alignments- must be geometrically balanced with the possibility of construction of the new buildings behind them, where structural geometries and functional measures must be attended. So, in this paper a series of clarifying samples are shown about the processes of public urban renewal implementation built in Valencia along the last third of 20th century.
\end{abstract}

Keywords: Old town, Urban renewal, Valencia, Urban fabric, Urban geometry.

\section{Ciutat Vella in Valencia: Old Town permanence and transformations}

As the many part of Western cities, Valencian old town preserves recognizable its general framework, the series of historical additions through centuries becoming the main part of the current city. Ciutat Vella, Valencian old town, maintains a clear permanence of the city parts even if compared with the city nowadays. In 1738 Priest Tosca draw up the first liable plan for Valencia, by detailing all the buildings and inner spaces into the blocks, as well. It contains at all a huge quantity of valuable information about 18th century Valencia. A comparison between that image a current aerial one of the city we can easily establish an immediate relationship between several parts in the city as well. In a first eyeshot we recognize the general characteristic lines of the city, especially possible due to the river presence - even when in 18th century the cities on a river were drawn "on it", and not in its cardinal placement-. And, consequently, we can read the trace of the disappeared walls turned into a modern ring avenue. In addition to this, into this almond-shape urban space some main buildings stay through centuries, such as Catedral or Lonja -the silk merchants' loggia-. And some other main pieces suddenly appear at the very beginning of 20th century, such as Mercat Central, Estació del Nord -the Northern 
Railway Company Station-, Ajuntament -Town Hall- or Correus -Main Post office-.

In parallel to all these buildings, the next point head us to identify into the aerial view new urban lines and spaces opened throughout the ancient urban fabric and did not exist on the ancient map. We meet new clear spaces such as the great one around the Catedral and its religious hinterland or the huge Ajuntament square and surroundings. And new, huge streets can be found as well in two unique cases: a narrow 19th century Paz Street, and a wide, middle-20th-century Avinguda de 1'Oest - both cases following the genuine French formula for boulevards in Paris. Just with this simple number of cases we confirm the changing life of the city, specifically carried out in ancient cities as the scenario of huge number of stories and periods.

But the great urban interventions carried out into Ciutat Vella in Valencia were executed along the 20th century with difference, as it happens in the rest of European or western cities too. In a smaller scale than previous grands-travaux, a huge number of alignment modifications, parcel additions, building replacement or modern constructions were implemented. And all they, as a whole, transformed the old town into a partially updated city for modern requirements.

We cannot forget that from Roman times -form the point of view of Western culturethe city is a continuously changeable entity, such as s biological one, being in a permament transformation to be updated to new times. This continuous updating of the city shows the appearance of new style buildings, but specially verify the permanence of streets tracing as shown before with Valencian images almost three centuries far. However, even the street delineations modifies partially, in parallel to the cultures or civilizations operating on them. Furthermore, many times mediaeval streets are the vague reflection of a former roman grid pattern, and often is deleted by the street aggrandizement of hygienist boulevards. At this point, nowadays civilization must preserve the historic city as a legacy form former times and cultures, as well as way or learning living lessons for the future.

\section{Three periods on 20th century transformations in Ciutat Vella}

Along those decisive changes produced along the 20th century into Ciutat Vella, three different periods of changes can be established separated. They're marked through the presence of both main political moment in Spanish 20th century: 30's Civil War and the very first Democracy after 1975. In an urbanistic context, two main year-dates can be established to refer to: 1931 and 1984 . 1931 is referred to as the publications year of the last town planning following 19th century principles. 1984 refers to the publication year of the first protection town planning rules for listing heritage buildings as well.

The first period, 1900-1931, is the time when urban renewal plans were developed following 19th century hygienist principles in Paris. There were two plans, in 1911 and 1929 and they were leaded by the municipality and signed by respective town hall master architects at each moment. Both plans cover the whole old town with punctual interventions throughout the historic urban pattern to adapt it to new times performed by the new Ensanches -19th century city extensions-. 1911 Plan de Reforma -Renewal Plan- was signed by Federico Aymamí and is the first 20th century renewal plan after the successful intervention done in Valencian Paz street. This plan was based in some proposals from later 19th century to sanitize city Centre widely funded on hygienist principles, defining two main interventions and a huge number of small ones. The next one, 1929 Plan de Reforma Interior -Inner Renewal Plan- was proposed bay Javier Goerlich, one of the greatest 20th century Valencian architects and, even more, the real author of the current city Centre townscape. Into this plan, huge interventions were reduced just to a single one -Avinguda de l'Oest- and a global treatment of corrections for old town.

These two plans were global proposals containing, for the last time in history, huge scale interventions in a haussmanian way. On the other hand, they started a different way of updating the historical urban pattern through a wide series of lesser urban corrections. They were not developed because of economic 

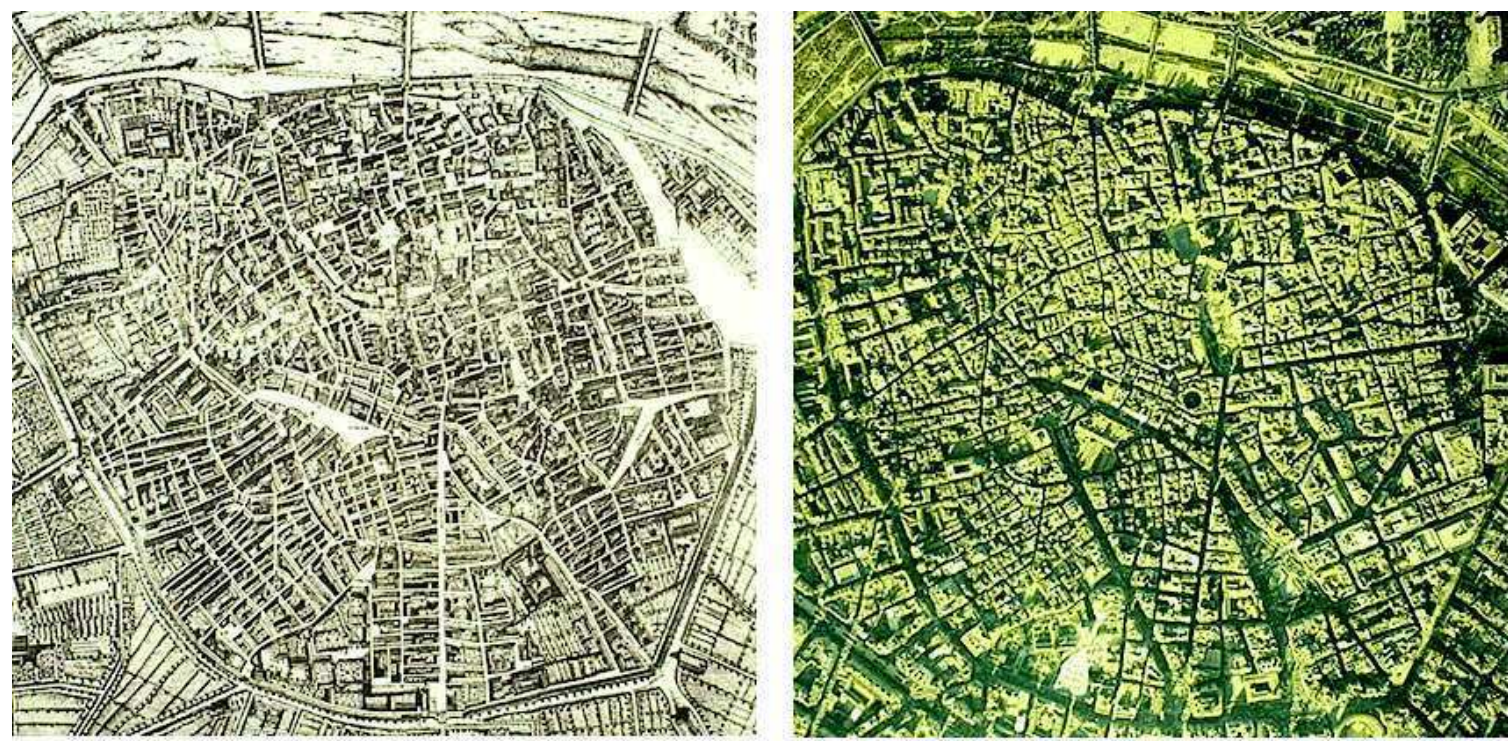

Figure 1.

Ciutat Vella over the course of centuries.

matters, and only a dozen buildings were risen up into the new urban alignments.

The second period, 1931-1984, covers half a century with no urbanistic activity. The economic depression after the Spanish Civil War on the one hand, and the national closure to outer influences till the democracy on the second hand, produced a time with no planning relievable production for the city. There were only some revisions on the existing town planning, as general strategic plans (1949 and 1966) or even such partial developments without an urban planning aim (1956).

If the first period symbolizes a sort of time for planning, this second one becomes the moment of practices and execution of works. However, there was only one huge case in an urban scale execution - the construction of Avinguda de l'Oest. At the same time, a big number of building substitutions were promoted as well. All these new buildings replaced former ones respecting the existing parcels or making very few changes of alignment.

Finally, the third period, 1984-2000, is the time to rethink the city after the Italian lecture on heritage protection specially held in Bologna. This new way for updating the city went deep into the new municipal democratic in Spain. And as a result, in 1984 a series of protection plans were draft for Ciutat Vella. But as a reaction to $70 \mathrm{~s}^{\prime}$ disorder, these plans became a straitjacket for refurbishment because of excess of protection points. So, a huge number of historic buildings fell down with no intervention because of its extremely exhaustive and expensive procedures. And these 1984 protection plans became the opposite effect to that intended.

With this dramatic scene, in 1992 a second protection plans were held in a more hands-off approach. This point was a turn to build reality and the possibility to refurbish old buildings into new uses and incorporation of new technics and materials. In an urban side, this less restrictive wave led to the possibility of old alignment changes ever thought in the former time. In this second group of town planning initiatives a huge care on historic urban pattern was developed, which will be carried out here bellow.

A comparison of the spirit of both groups of plans -form 1984 and 1992- can be seen in the schemes bellow, where the red points show in both cases the number of public space modifications. As can be seen easily, the number of modification proposals in 1992 is too high that that in 1982. [Fig.2, A and B]

Finally, 20th century finishes with a last third group of town planning proposals because a regional heritage law was published in 1994. This law led again the prominence to strict rules for intervention on historic buildings and urban heritage. 

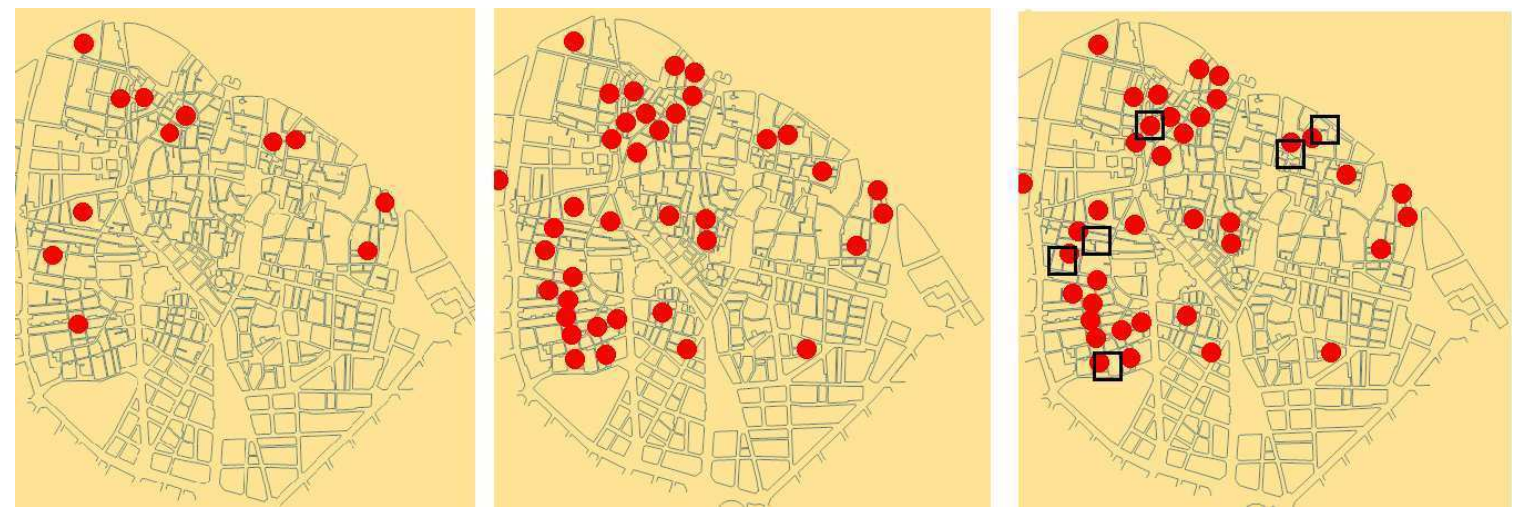

Figure 2.

Alignment modifications in Ciutat Vella in 1984 plans (A) and 1991 ones (B). Case studies situation (C).

\section{Historical geometry into later alignments}

After this general overview on 20th century town planning in Ciutat Vella, there is a period where a specific attention must be payed: that of the 1990s proposals. Into that 20th century third period, town planning carried out by public administrations developed a special care on the existing urban fabric. The plans for the five quarters -in which Ciutat Vella was divided- have a common technical approach for further design, taking profit from old town to update old town.

Even though that division of Ciutat Vella into five quarters has quite artificial matters, it remains the basic differences between the different corners of the common historic enclosure, as explained before, with its own urban genesis, parceling evolution and built heritage. Therefore, it evidences the character of the four corners and the central area itself. In addition, the graduation of those characters can be seen from the modest and popular NW area -Barri del Carme-, to the bourgeois and dynamic SE one -Barri de Sant Francesc-; or between historical and highly heritage graded NE area -Barri de la Seu i la Xerea-, to the latest, silk-workers' SW quarter -Barri dels Velluters-. In the middle, the area around the central market -Barri del Mercat- stays almost invariant undoubtedly because this part remains loyal to the city origin character itself as an important trading center.

Between 1991 and 1993, public administration pushed up those special planning figures to update the ancient city definitively. Moreover, because of the presence of buildings heritage and their own story, all the efforts were focused on the west side of the old town. In fact, this part had a lower evolution far away from the new Centre at SE of Ciutat Vella in connection to new ensanches. That was why the autonomous government, in collaboration with the municipal one, signed a convention for the regeneration of the whole city centre, specially developed for NW and SW quarters - Carme and Velluters respectively. In both quarters, the point was to respect the existing city through town planning, where town planners would have to use the existing geometry of the historic parcels as an essential issue for the materialization of that regeneration.

Different teams of architects and planners drew up Ciutat Vella urban plans, and they indiscriminately used a common tool. That one was the junction of the existing geometry of the parcels and urban spaces together with the forthcoming geometry of the new buildings to be inhabited. New alignments were drawn both to become further buildings and to create the curtain façade of the new urban spaces as well.

As a selection of some specific practices, hereby six cases of final materialization of town planning proposals will be shown. These case studies are the legacy of a technical practice in a precise period of time that will never happen again. Both urban and heritage regulations preserve the historic city to future generations. Moreover, the interesting point produced along these years -between 1992 and 1998- is to mark the technicians' skills to keep a balance between updating the ancient scene and create profitable buildings. We can find bellow three samples in each western 

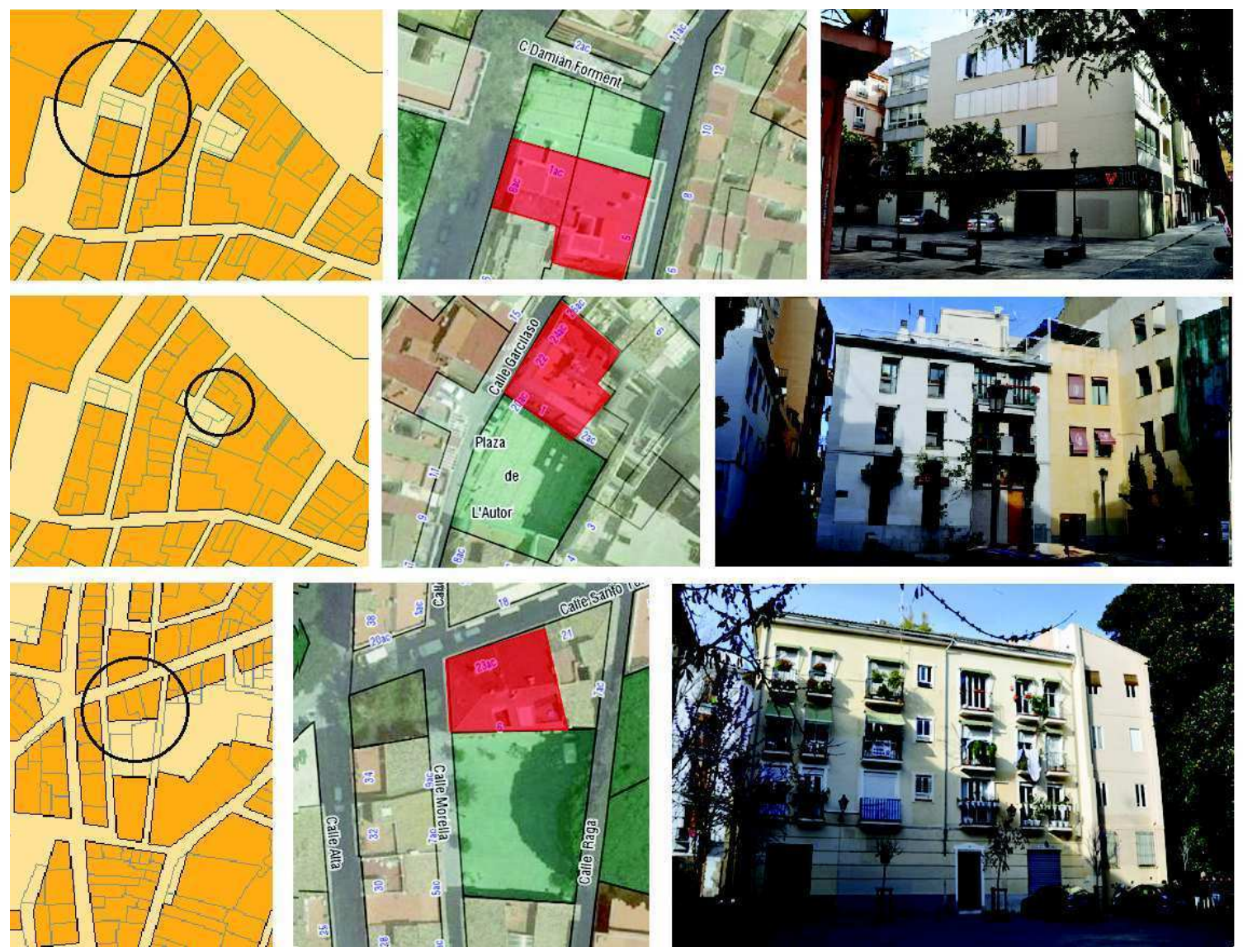

Figure 3.

Barri del Carme case studies: Moret, 5; Garcilaso, 22; Morella, 6.

quarters in Ciutat Vella: Carme and Velluters. These were the concentration area of all the regeneration efforts in that period.

These cases show the transformation of ancient urban pattern for solving "died" situations in it, such as narrow constrictions or dead ends -cull-de-sacs-. Thus, in all these cases the ancient pattern is broken for expanding or connecting streets to achieve a sort of modern updating of the antiquity. The more frequent situation is to make wider a former narrow street. The second one is to trespass the block extending a cull-de-sac - or to create a tangential urban square in the crossing point of the existing street and the cull-de-sac. A third situation is to open an emptying into one block, in a similar way to Italian sventramento.

Therefore, these cases can be reviewed in detail to appreciate the power of geometry to create new, coherent urban space through new buildings. On one side, we will consider three cases in Barri del Carme, the more NorthWestern quarter in Valencia old town covering almost a real forth part of the initial surrounding circle walls. On the other hand, we "will attend other three cases at Barri dels Velluters, which is the more South-Western quarter in Valencia old town and covers a third part of the former circle walls length.

\section{Barri del Carme cases}

This area has its origin out of the muslim town -the second city walls circle-, and emerged as an outter side of the city as a slum area or a kind of suburb of it. However, it allways had a modest, humble background. Because of that origin out of the formal city, its urban patern is a result of a spontaneous extencion of streets inperpendicular to the roads arriving to the city. So, there is a narrow width in the streets, no parallelism or seriation, and it is the presence of several cul-de-sac as well, as a heritage of the muslim origine of this area, as we can see in the three cases shown [Fig.3]. 

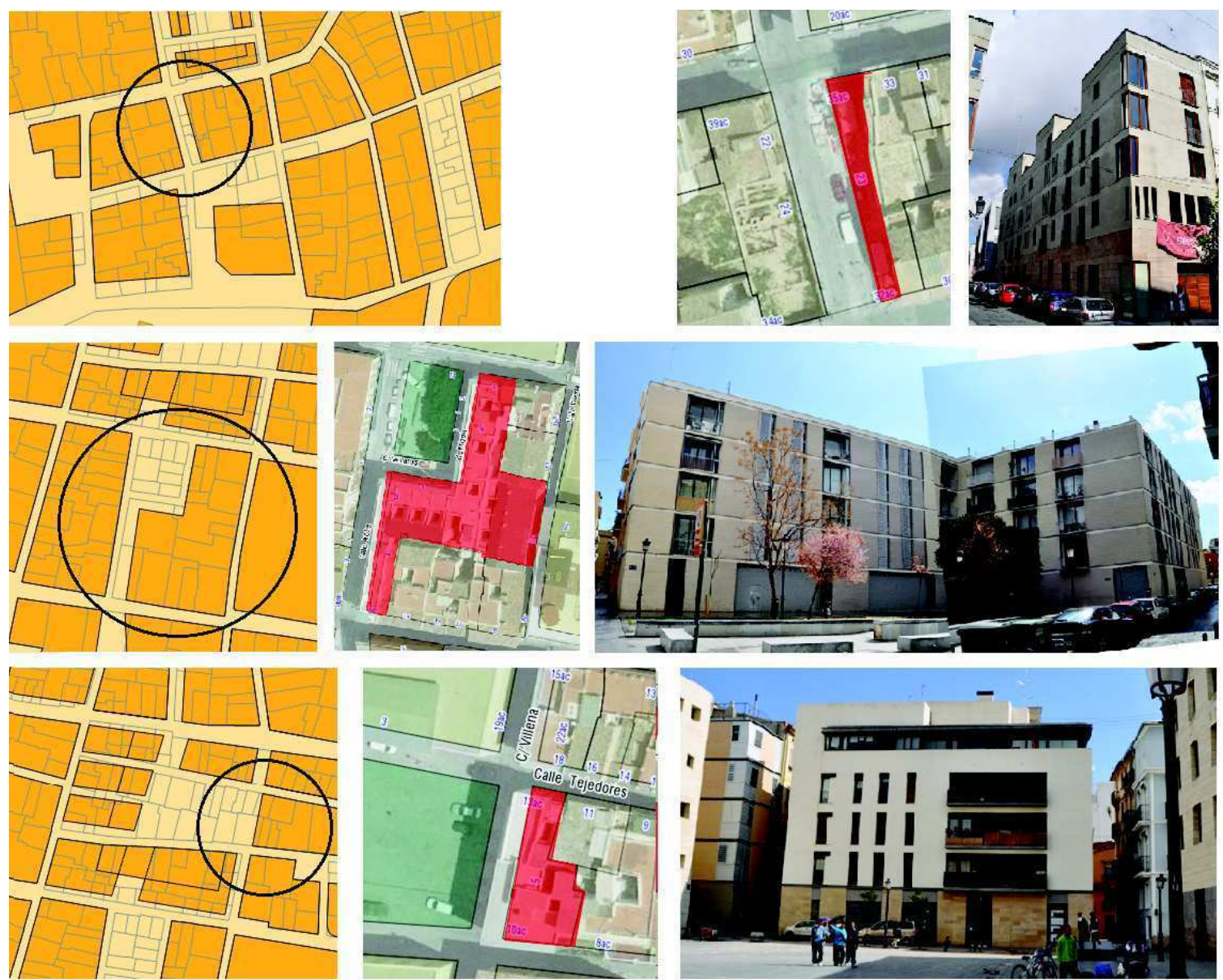

Figure 4.

Barri dels Velluters case studies: Maldonado, 33; Arolas, 4; Villena, 5.

Case 1: Moret 1. An existing short street or pass between two long, winding streets is the base to extend it to vreating a kind of urban square at its south façade by shortening southern block. On the basis of the existing parcels, just five of them were demolished in order to creta a new,large one with $22,60 \mathrm{~m}$. wide and 10 and $16 \mathrm{~m}$. depth in both sides. So a huge, new plot is created on $300 \mathrm{sqm}$, devoted to social housing.

Case 2: Plaça de l'Autor 1. The presence of an old, abandoned cul-de-sac is the basis to create a new urban square tangential to the main sreet. So, south and bottom façades of the cul-de-sac remain, a the northern one is eliminated to be removed to parcels free. In this case, the existsting parcel as a new façade is re-built with a new, small building facing the new space - emerging a 190 sqm plot.

Case 3: Morella 6. This third case in Barri del Carme has a similar situation than the first one, but without an existing cul-de-sac. Two long existing blocks, with a very bad situation o central builindgs is profitted to open a new urban square conecting both streets, by demolishing three parcels. South side - a kind of ancient inn- will open windows to the new space, such as one of the northern parcels. The other one in the north is rebuilt, on a plot of $218 \mathrm{sqm}$ and four stoery high devote to social houisng as well.

\section{Barri dels Velluters cases}

This area requires special apreciations because is the last one to be created into the chistian walls, and it has different urban pattern as genesis. All the area was out of the walls til 14th century. With the construction of the third, Christian city walls, a new urban area was developed by more or less parallel 
streets towras outside of the city with $\mathrm{E}$ to $\mathrm{W}$ orientation, and a few number of streets form $\mathrm{N}$ to $\mathrm{S}$. So, a kind of urban, spontaneous grill was formed, with the basis of existing roads and, specially, waterways or irrigation ditches. These are the origin of several craft workshops devoted to silk.

With that conditions, the general case in this quarter interventions is the existing street widening, creating new, narrow and long parcels to be re-built. As it has been said before, there were few, narrow streets in N-S orientation, and the new public intervention dicide to create a new, wider N-S axis torough the quarter as an own vertabration one for it, on the basis of former Carrasquer, Arolas and Recaredo streets. Three selected cases are commented, and can be seen in the image [Fig.4].

Case 4: Maldonado 33. In the most southern part of that new Carrasquer-Arolas-Recaredo axis, a new very narrow and too long parcel is created by widening Recaredo strret. As an outcome, there is a plot $35 \mathrm{~m}$. long by 4 and $7 \mathrm{~m}$. deep, and finally a near $190 \mathrm{sqm}$ area for a 5 story high building. In other terms, the architectural solution had the merit of avoiding a boring, long new façade, emulating the broken rythm of the ancient buildings cornices.

Case 5: Arolas 4. In the middle of the aforementioned axis, an interesting intervention was developed covering a huge part of a former "L" shaped block. Arolas street was widened, and several ancient buildings were in ruins, to be substituted by a huge one in an intrincated, irregular shape. The eliminations af a very smal NW block into the "L" area helps to create an interesting new urban space.

In this case, the complicated geometry created façades 41,20 and $32 \mathrm{~m}$. long, and depths 10,16 or $4 \mathrm{~m}$., in an unquestionalbe, high quality result.

Case 6: Villena 5. The final case is located in the only huge square planned in the middle of Carrasquer-Arolas-Recaredo axis: Viriato square. This square was planned by the elimination of the central part of a former long block - but the subsequent archaeological excavations confirmed the intial existence of a pass in this point, for serenity of openings reluctants. In this case, a set of 4 parcels were combined to form a new one, $23 \mathrm{~m}$. long and 5 and $10 \mathrm{~m}$. deep, with a few more than $180 \mathrm{sqm}$. area and 5 storey high new building faceing the new square.

\section{Conclusion}

The six cases studied tackle the importance of the ancient parcels geometry for the transformations of old town, Ciutat Vella. Current Spanish and Valencian urban regulations protect the historic shadow of ancient buildings and alignments, and it is not possible to modify the historic tracks, but in the third part of 20th century there was a group of urban interventions that had to have a deep knowledge of the existing city in order to update it by modifying it.

Old town is a set of ancient parcels that emerged with no organization through history, and whose geometry is the base fornew buildings and uses in further urban interventions. Thus, existing geometry finally provides physic plots for new urban spaces and buildings pieces with specific requirements due to their functionalism and mass materialization. This becomes a very useful technique to handle when acting -if regulations allow it- in old town for urban renewal interventions.

\section{References}

Casao, R., García, M. et alt., (2009) Otra mirada a la reforma interior (Ajuntament de València, Valencia).

Colomer, V. et alt. (2002) Registro de Arquitectura y Espacios Urbanos del Siglo $\mathrm{XX}$ de la Comunidad Valenciana (COACV - COPUT - IVE, Valencia).

Gaja, F. (2001) Intervenciones en Centros Históricos de la Comunidad Valenciana (C.O.P.U.T. / COACV. Valencia)

Llopis, A. Y Perdigón, L. (2010) Cartografía histórica de la ciudad de Valencia (16081944) Ajuntament de València, Valencia).

Pecourt, J. et alt. (1999). 5 años. (ÍCARO CTAV, Valencia).

Taberner, F., Pecourt, J. et alt. (1992) Ciutat Vella: Materiales para el urbanismo 
(COACV, Valencia).

Taberner, F. et alt. (2000) Historia de la Ciudad. Recorrido histórico por la arquitectura y el urbanismo de la ciudad de Valencia (COACV, Valencia).

VV.AA. (1994) Atlas histórico de ciudades europeas, Península Ibérica (Centre de Cultura Contemporània de Barcelona, Salvat Editores, S.A., Barcelona). 